\title{
B.І. Єфріменко
}

\section{СЕРЕДИННА ГРАНИЦЯ КАРБОНУ В ДОНБАСІ (ЗА ФОРАМІНІФЕРАМИ ТА ВОДОРОСТЯМИ)}

\section{V.I. Efimenko \\ THE MID-CARBONIFEROUS BOUNDARY IN DONBASS (BY FORAMINIFERA AND ALGAE)}

Виявлені найбільш суттєві рубежі в еволюційному розвитку форамініфер і водоростей Донбасу у перехідний ранньо-середньокам'яновугільний час. На основі аналізу еволюційного розвитку форамініфер і вапнистих водоростей та зміни їх видового різноманіття на границі серпуховського і башкирского ярусів виявлені регіональні та планетарні біологічні маркери для обгрунтування серединної границі карбону у Донбасі.

Ключові слова: форамініфери, водорості, серпуховський ярус, башкирський ярус, карбон, Донбас.

Выявлены наиболее существенные рубежи в эволюционном развитии фораминифер и водорослей Донбасса в переходное ранне-среднекаменноугольное время. На основании анализа эволюционного развития фораминифер и известковых водорослей и изменения их видового разнообразия на границе серпуховского и башкирского ярусов выявлены региональные и планетарные биологические маркеры для обоснования срединной границы карбона в Донбассе.

Ключевые слова: фораминиферы, водоросли, серпуховский ярус, башкирский ярус, карбон, Донбасс.

The most significant levels in the evolution of Donbass foraminifera and algae at transitjonal early - middle carboniferous time was revealed. On a base of analysis of evolution development of foraminifera and algae and changes of its species variety on the Serpuhovian-Bashkirian transition was revealed a regional and global biological markers for establishment of Mid-carboniferous boundary in the Donbass.

Key words: foraminifera, algae, Serpukhovian Stage, Bashkirian Stage, Carboniferous, Donets Basin.

\section{ВСТУП}

Однією $з$ найскладніших проблем стратиграфії палеозою $€$ виявлення головного планетарного рубежу в середині кам'яновугільної системи, тобто границі між міссісіпською та пенсільванською підсистемами (Mississippian - Pensilvanian), або ж серпуховським і башкирським ярусами, згідно з Глобальною стратиграфічною шкалою (Global Stratigraphic Scale - GSS). Історія розв'язання проблеми серединної границі карбону докладно висвітлена у роботі автора [3]. У розвитку уявлень про серединну кам'яновугільну границю для її фіксації було запропоновано кілька рівнів, які з часом понижувались. Їх вибір ґрунтувався на різних концепціях, при відсутності загальноприйнятих принципів і чітких критеріїв визначення стратиграфічних границь. У 1976 р. Міжнародний геологічний союз IUGS (International Union of Geological Sciences) офріційно рекомендував для встановлення границь так звану операціональну методику, яка передбачає встановлення положення границі у кон- кретному розрізі за допомогою палеобіологічного репера [11].

Провідну роль у визначенні серединної границі карбону відведено найбільш корелятивним групам - гоніатитам, конодонтам та форамініферам. За результатами досліджень різних груп кам'яновугільної фауни та флори багатьох регіонів світу на рівні підошви гоніатитової генозони Homoceras, що приблизно відповідає границі міссісіпій - пенсільваній відбулася як не найсильніша біологічна криза в карбоні, коли у відносно короткий час майже серед усіх груп фауни і фллори зникло багато ранньокам'яновугільних видів. На цьому рівні встановлена евстатична секвенс-границя у багатьох розрізах світу та подекуди зафіксована перерва осадконакопичення [2, 12, 15, 20]. 3 числених розрізів-кандидатів на стратотип границі (Global Stratotype Section and Point - GSSP) було обрано і затверджено розріз Ерроу-Каньон у Південній Неваді, США (Arrow Canyon). Після внесення уточнень до його біостратиграфічної характеристики серединна 
карбонова границя на сьогодні приймається в інтервалі переходу амоноїдних зон Eumorphoceras-Homoceras за появою конодонтів Declinognathodus noduliferus s. I. в їх еволюціїній послідовності, а в разі відсутності таких - за появою допоміжних форм: конодонтів Rhachistognathus primus (Dunn), R. minutus (Higgins et Bouckaert); форамініфрер Millerella pressa Thomp., $M$. marblensis Thomp., Globivalvulina bulloides (Brady) [10, 13].

у 2006 р. Міжнародною підкомісією зі стратиграфії карбону (Subcommission on Carboniferous Stratigraphy - SCCS) була офріційно прийнята в якості регіональної ярусна шкала карбону Східної Європи (Центральної Росії та Донбасу) [14], з якої випливає, що проблема серединної границі карбону у даному регіоні $€$ власне проблемою границі запалтюбинського та вознесенського горизонтів. Оскільки дані горизонти були виділені у Донбасі, важливим $є$ виявлення головного планетарного рубежу в середині кам'яновугільної системи (рівня, що відповідає GSSP) в стратотиповій місцевості. Амоноідеї зони Eumorphoceras востаннє зустрічаються у Донбасі вище вапняку $D_{5}^{7}$, а перші Homoceras - в $D_{5}^{10}$. Проте, оскільки поява Homoceras у розрізілімітотипі майже збігається з появою конодонтів Declinognathodus noduliferus (Ellison et Graves), нижній рівень зони Homoceras у Донбасі приймається за появою згаданих конодонтів, а границя нижнього і середнього карбону $\left(\mathrm{C}_{1}-\mathrm{C}_{2}\right)$ - в основі конодонтової зони Declinognathodus noduliferus S. I. за появою Declinognathodus inaequalis (Higgins) у вапняку $D_{5}^{8}$ в [16-18].

Чітких же критеріїв визначення серединної границі у Донбасі за фрорамініферами досі не встановлено, що на практиці ускладнює, а іноді унеможливлює розчленування нижньо-середньокам'яновугільних відкладів регіону. На сьогодні форамініфери, на основі вивчення яких розроблені діючі стратиграфрічні схеми кам'яновугільних відкладів східних областей України 1993 р. $[8,9]$, продовжують бути найбільш масовою та надійною провідною біостратиграфічною групою викопних організмів у розчленуванні кам'яновугільних відкладів. Вони мають тривалу історію вивчення (близько 150 років), потужну базу даних і добре розроблену систематику. Проте останнім часом з'явилися нові дані про стратиграфрічне і географрічне поширення форамініфер, відбулися суттєві зміни у поглядах науковців на систематику та еволюцію форамініфер тощо. Для вирішення даної стратиграфрічної проблеми карбону ми також залучили вапнисті водорості, які відігравали важливу роль в карбонатному осадкоутворенні Донбасу та мають стратиграфічний потенціал.

\section{МАТЕРІАЛИ ТА МЕТОДИ}

Пограничні серпуховсько-башкирські відклади вивчались автором в обсязі трьох горизонтів: запалтюбинського, вознесенського (світа $\mathrm{C}_{1}^{4}-$ зони $\mathrm{C}_{1}^{\mathrm{s} e}, \mathrm{C}_{1}^{\mathrm{sf}}, \mathrm{C}_{1}^{\mathrm{s}} \mathrm{g}$ ) та фенінського (частина світи $\mathrm{C}_{2}^{0}$ - за старою номенклатурою $\mathrm{C}_{1}^{5}-$ комплексної підзони $\mathrm{C}_{2}^{\mathrm{b}} \mathrm{a}^{\mathrm{H}}$ ) у природних та штучних відслоненнях опорних розрізів Донбасу. Даний інтервал представлений потужною (близько 700 м) ритмічно складеною товщею переверствування теригенних відкладів (аргілітів, алевролітів і пісковиків) з численними прошарками вапняків і вугілля.

Вивчений матеріал складають колекції шліфів із зразків, зібраних в різні роки О.І. Берченко, М.В. Вдовенко, Д.Е. Айзенвергом, Н.П. Василюк, та власних польових зборів автора 2004-2007 рр. з численних відслонень, розташованих у південній зоні дрібної складчастостіДонбасу (Донецька область, район Старобешево), a саме: у басейні р. Кальміус (так званому Кальміуському розрізі Донбасу, який свого часу був запропонований у кандидати на стратотип серединнокам'яновугільної границі) по обидва береги, з її численними балками, ярами та річками (на правому березі р. Берестова, на південному і західному берегах Старобешівського водосховища - у балках Желвакова, Султан-Бій-Тарама, Крива, Адаман-Чалган, Безіменна, Глибокий ярок, а також на схилах гори Запал-Тюбе проти с. Вознесенка, на лівому березі та в обводному каналі р. Берестова в урочищі «Чорна Скеля») та в Амвросіївському районі на лівому схилі балки Широкої (на схід від с. Григорівка). Загалом, було опрацьовано понад 5000 шліфів з близько 1000 зразків із застосуванням масового фотографування.

Для обґрунтування міссісіпсько-пенсільванської границі (М-П) у Донбасі ми використали переважно нові результати власних мікропалеонтологічних досліджень в тонких 
палеонтологічних шліфрах, що базувались на детальному вивченні систематики (з використанням новітньої номенклатури) та еволюції провідної стратиграфочно важливої групи фрауни форамініфер у комплексі з вапнистими водоростями. Фотозображення та поширення найбільш стратиграфічно важливих видів форамініфер і водоростей наведені в табл. I, II та на рис. 1.

Оскільки вивчення кам'яновугільних форамініфер Донбасу було розпочато ще в 1938 р. Н.Є. Бражніковою та Л.Г. Дайн, а згодом продовжено М.Ф. Манукаловою, М.В. Ярцевою, Г.Д. Киреєвою, Р.А. Ганеліною, П.Д. Потієвською, М.В. Вдовенко, O.І. Масло та ін., автор враховував не тільки власні розробки, а й інтерпретував 3 сучасних позицій дані, наведені у численних публікаціях попередніх дослідників. На жаль, вивченню водоростей досліджуваного інтервалу карбону у Донбасі приділялось значно менше уваги. Дані цих одиничних публікацій автор також враховував при роботі.

\section{РЕЗУЛЬТАТИ ТА ЇХ ОБГОВОРЕННЯ}

Фауна форамініфер на рубежі М-П переживала глобальну біологічну перебудову, так би мовити переломний момент у еволюції. Вперше оновлення складу фауни форамініфер у верхній частині світи $\mathrm{C}_{1}^{4}$ (група вапняків $D_{7}$ ) виявила ще у 1951 р. Н.Є. Бражнікова [1]. Початок оновлення вбачав пізніше і О.І. Масло на рівні вапняку $\mathrm{D}_{5}^{10}[4,21]$.

Вже на початку фрормування запалтюбинського горизонту (вапняк $D_{3}$ ) пізньосерпуховська фауна форамініфер, серед яких продовжують зустрічатися і деякі типові візейські види, досить різко починає збіднюватись. Майже одночасно 3 масовим вимиранням старих форм з'являються форми - носії нових ознак майбутньої башкирської фрауни. Це перехідні форми, серед яких зустрічається безліч своєрідних особин з незвичними, спотвореними черепашками. У представників різних груп відмічається паралельний розвиток однакових ознак, а саме: розгортання спіралі черепашки (як, наприклад, у планоендотир Planoendothyra (Iriclinella) spirilliniformis (Brazhn. et Pot.), ситоподібні устя, сплощеність черепашок, гігантизм, коливання осі навивання черепашок тощо. Така підвищена мінливість, варіабільність та масове вимирання старих форм, як зазначала К.О. Рейтлінгер, зазвичай характерні для останньої ідіоадаптивної фрази кожного етапу еволюційного розвитку фауни фрорамініфер $[5,6]$. Проте можна впевнено вважати, що, крім закономірних біологічних перетворень, фауна форамініфрер у запалтюбинський час зазнала серйозних екологічних потрясінь. Нестабільний морський басейн (що зафріксовано у розрізі відкладів) спонукав форамініфер пристосовуватись до нових умов життя. За цих обставин виникало, як уже сказано, багато спотворених форм. Щоправда, більшість з них виявились недовговічними. Серед таких форм часто трапляються ендеміки. Проте у деяких форамініфер нові отримані ознаки закріпились. Такі форми стали родоначальниками оновленої пізньокам'яновугільної фауни. Так, у запалтюбинський час значне коливання осі навивання черепашок роду Eostaffella призвело до появи перших шароподібних представників нового роду Plectostaffella, які спочатку існували без чітко виражених видових ознак. Саме появою Plectostaffella varvariensis (Brazhn. et Pot.) та Pl. bogdanovkensis Reitl. маркується початок башкирського часу в багатьох регіонах світу. Проте у Донбасі перші особини, що несли у собі ознаки цього роду з'являються раніше, а носії чітких видових ознак згаданих двох видів фріксуються нами у вапняку $D_{5}^{9}$. Саме на цьому рубежі в карбоні Уралу O.І. Кулагіна також відмічала становлення роду Plectostaffella та масове вимирання ранньокам'яновугільних форм [4]. Від примітивних плектоштафел на початку фенінського часу в результаті коливання осі навивання до $90^{\circ}$ виник рід Semistaffella. Останній, у свою чергу, дав початок існуванню субсферичних Pseudostaffella. Таким чином, біологічні та геологічні (палеоекологічні) процеси, що відбувались у запалтюбинський час, призвели до появи та прогресивного розвитку родини Pseudostaffellidae.

Важливі ароморфні перетворення переживала у перехідний ранньо-пізньокам'яновугільний час родина Lasiodiscidae. У запалтюбинський час вимерли майже усі Howchinia, у вознесенський час продовжували існувати Monotaxinoides, але вже поступилися місцем роду Eolasiodiscus 
3 ускладненими додатковими устями. Значних еволюційних змін зазнали також архедисциди. На зміну старим візейським i серпуховським формам (приблизно на рубежі вапняку $\left.D_{5}^{8} B\right)$ з грубопористою склувато-променистою стінкою та темним внутрішнім шаром груп Archaediscus karreri (Brady), Arch. krestovnikovi Raus. приходять здебільшого дрібні сплощені форми зі світлою тонкопористою стінкою - групи Archaediscus subcilindricus Brazhn. et Pot., Arch. donetzianus Sosn., Arch. Iongus Pot., часті неоархедискуси - Neoarchaediscus probatus (Reitl.), N. incertus (Grozd. et Leb.), N. timanicus (Reitl.), N. rectus (Kir.), N. gregorii (Dain) та астероархедискуси Asteroarchaediscus subbaschkiricus (Reitl.), Ast. baschkiricus (Krest. et Theod.) та багато ін. Еволюційні зміни відбуваються і у родині Tetrataxidae. Серед численних різноманітних тетратаксисів наприкінці вознесенського часу (у вапняку $D_{7}^{7}$ ) з'являються крупні тупоконічні 3 широкою основою представники роду - Tetrataxis cf. planolocula Lee et Chen, T. parviconica Lee et Chen та ін.

Характерний серпуховський рід Eosigmoilina виявився недовговічним. Останній його представник Eosigmoilina robertsoni (Brady) вище вапняку $D_{5}^{9}$ у Донбасі не виявлений. Новими елементами фауни пізньосерпуховського часу $є$ деякі представники родів Pseudoglomospira i Tolypammina, які продовжували існувати у ранньому башкирі.

Значні перетворення відбувались також у родині Biseriamminidae. Крупні представники цієї родини - Globivalvulina - 3 багатокамерною черепашкою і відносно товстою стінкою 3'явились ще наприкінці протвинського часу. Проте типовий представник роду із закріпленою ознакою диференційованою тришаровою стінкою Globivalvulina bulloides був виявлений нами у Донбасі у відкладах вознесенського та фенінського горизонтів, починаючи з вапняку $\mathrm{D}_{7}^{2}$.

Панівний же стан серед фауни запалтюбинського-вознесенського часу мав представник родини Eostaffellidae - рід Eostaffella, якому зобов'язані появою і плектоштафели, і семіштафели, і високорозвинуті фузулініди. Еоштафели запалтюбинського часу представлені численними, переважно дрібними мінливими формами. В еволюційному розвитку еоштафел помітна тенденція розвитку сплощених форм. Так, на початку вознесенського часу з'являються Eostaffella pseudostruvei (Raus. et Bel.), E. chomatifera Kir. та перші представники роду Millerella - M. pressa та плоскі форми М. angusta (Kir.) (з вапняку $D_{5}^{9}$ ), а пізніше поступово з'являються і інші представники родини Eostaffellidae - рід Plectomillerella (з вапняку $D_{5}^{10}$ ) і сплощені Millerella marblensis, M. uralica Kir. (3 вапняку $D_{7}^{2}$ ) та Seminovella (з вапняку $D_{7}^{4}$ ). Ця ж тенденція прослідковується і у фенінський час, коли з'явились $E$. compressa Brazhn., E. acutissima Kir. та ін. Поряд зі сплощеними формами, у вознесенський час 3'являються крупні E. designata (D. Zeller) та $E$. aff. pinguis (Thomp.), a y фeнінський час - дещо роздуті E. kashirica Raus. У фенінський час важливою поді$\epsilon ю$ у еволюції фрауни форамініфер стала поява перших представників родини Pseudostaffellidae - Semistaffella (з вапняку $E_{1} \mathrm{H}=\mathrm{D}_{8}$ ), яка надалі отримала розвиток у пізньому карбоні і, вірогідно, була предковою для Pseudostaffella, яка з'являється у мануйлівському горизонті.

Серед доволі частих у запалтюбинських і вознесенських відкладах бредіїн переважають Bradyina cribrostomata Raus. et Reitl., Br. concinna Reitl., Br. magna Roth. et Skin. У фенінський час з'являються перші фрорми родини Bradyinidae зі складною керіотекою стінки черепашки - Bradyinelloides cf. pseudonautiliformis (Reitl.).

В цілому, збідніла фауна форамініфер світи $\mathrm{C}_{2}^{0}(\mathrm{E})$ дуже подібна до фауни верхів світи $\mathrm{C}_{1}^{4}$ (комплекс вапняків $\mathrm{D}_{7}$ ). Продовжували існувати головним чином види широкого вертикального поширення.

Усі вапняки запалтюбинського, вознесенського та фенінського горизонтів охарактеризовані досить різноманітними за систематичним складом і співвідношенням водоростями. Загалом, тут їх визначено понад 40 видів, що належать до 38 родів. На підставі аналізу поширення водоростей у пограничних верхньосерпуховських-нижньобашкирських відкладах вдалося визначити декілька важливих етапів їх еволюційного розвитку. В запалтюбинський час продовжують існувати типові серпуховські форми: Praedonezella cespeformis Kul., Ungdarella uralica Masl. та Archaeolithophyllum mis- 
Таблиця I

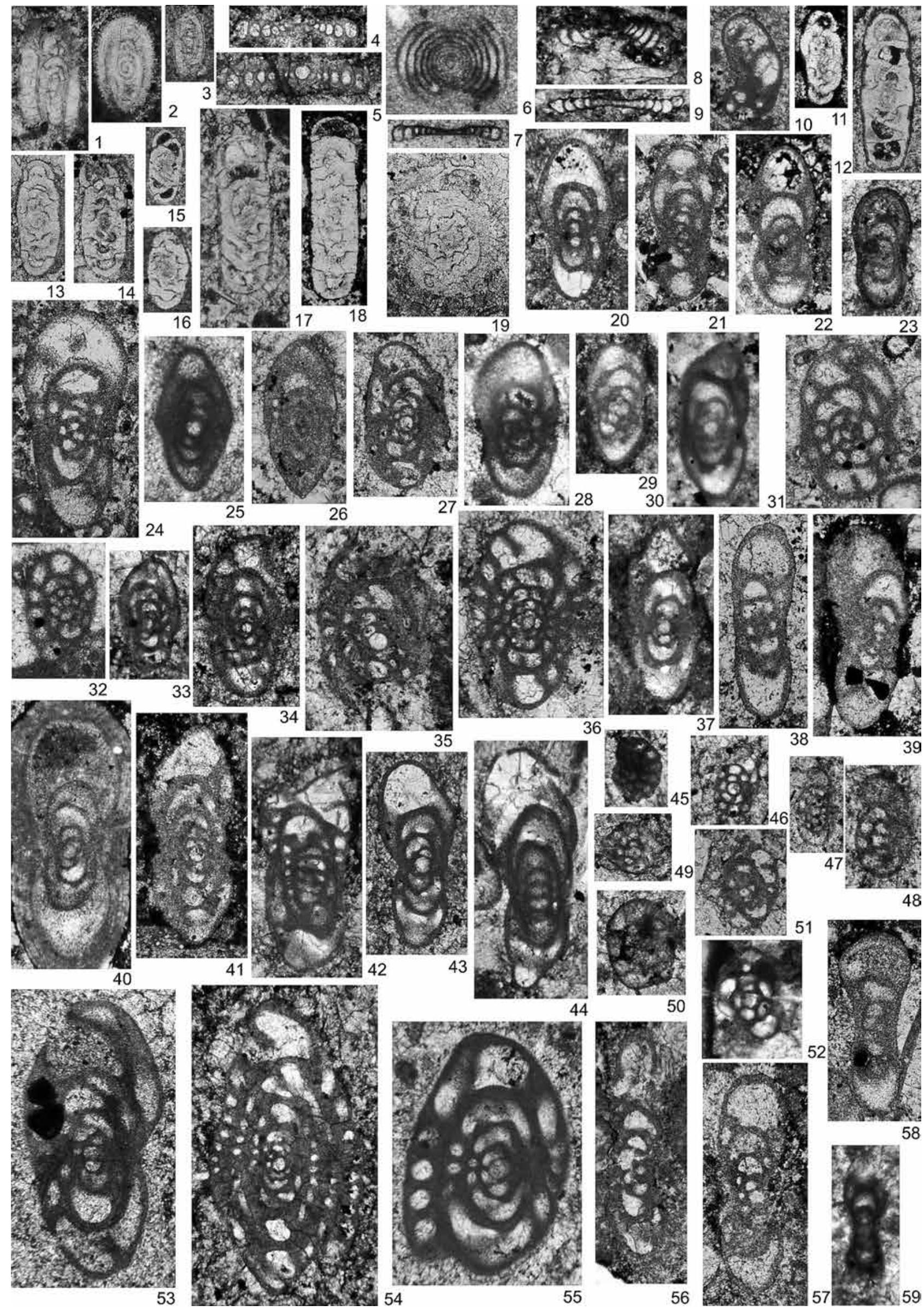


Таблиця I

Стратиграфрічно важливі види форамініфер в пограничних міссісіпсько-пенсільванських відкладах x 100

1-3 - Eosigmoilina robertsoni (Brady); 1 - правий берег р. Кальміус, смт. Старобешеве, запалтюбинський горизонт, вапн. $\mathrm{D}_{3} ; 2$ - північний схил г. Запал-Тюбе, правий берег р. Кальміус, с. Вознесенка, Старобешівський р-н, запалтюбинський горизонт, вапн. $\mathrm{D}_{5}$; 3 - p. Кальміус, б. Желвакова, смт. Старобешеве, запалтюбинський горизонт, вапн. $D_{5}^{6}$; 4, 5 - Monotaxinoides transitorius Brazhn. et Jar.; г. Запал-Тюбе, правий берег р. Кальміус, с. Вознесенка,

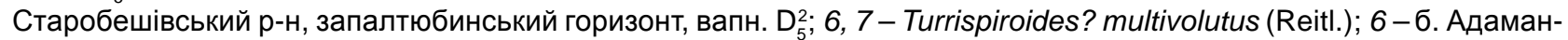
Чалган, правий берег р. Берестова, Старобешівський p-н, запалтюбинський горизонт, вапн. $D_{5} ; 7-$ p. Кальміус, б. Безіменна, смт. Старобешеве, запалтюбинський горизонт, вапн. D5; ; 8, 9 - Eolasiodiscus sp.; г. Запал-Тюбе, правий берег р. Кальміус, с. Вознесенка, Старобешівський р-н, запалтюбинський горизонт, вапн. D2; 10 - Globivalvulina bulloides (Brady); смт. Старобешеве, вознесенський горизонт, вапн. $\mathrm{D}_{7}^{2} ; 11$ - Neoarchaediscus ex gr. postrugosus (Reitl.); р. Кальміус, б. Желвакова, смт. Старобешеве, вознесенський горизонт, вапн. $\mathrm{D}_{5}^{10} ; 12$ - Neoarchaediscus incertus (Grozd. et Leb.); там само, вапн. D; 13 - Neoarchaediscus gregorii (Dain); р. Берестова, с. Обільне, Старобешівський р-н, вознесенський горизонт, вапн. D $; 14$ - Neoarchaediscus probatus (Reitl.); с. Олександрівка, Старобешівський р-н, фенінський горизонт, вапн. E $_{5} ; 15$ - Neoarchaediscus aff. parvus (Raus.); правий берег р. Берестова, вище греблі на захід від с. Олександрівка, Старобешівський p-н, вознесенський горизонт, вапн. D5; 16 - Asteroarchaediscus subbaschkiricus (Reitl.); там само; 17 - Planospirodiscus borealis (Reitl.); p. Берестова, с. Обільне, Старобешівський р-н, вознесенський горизонт, вапн. D ; 18-Planospirodiscus aff. minimus (Grozd. et Leb.); p. Кальміус, смт. Старобешеве, вознесенський горизонт, вапн. $\mathrm{D}_{7}^{4} ; 19$ - Asteroarchaediscus baschkiricus (Krest. et Theod.); с. Олександрівка, Старобешівський р-н, фенінський горизонт, вапн. $\mathrm{E}_{4} ; 20$ - Eostaffella acutiformis Kir.; р. Кальміус, смт. Старобешеве, запалтюбинський горизонт, вапн. D 6 ; 21 - Eostaffella chomatifera Kir.; p. Кальміус, смт. Старобешеве, вознесенський горизонт, вапн. Dㄱ; 22 - Eostaffella pseudostruvei (Raus. et Bel.); правий берег р. Берестова, с. Олександрівка, Старобешівський р-н, вознесенський горизонт, вапн. D5; 23 - Eostaffella postmosquensis Kir.; урочище «Чорна скеля», лівий берег р. Берестова, смт. Старобешеве, френінський горизонт, вапн. $\mathrm{E}_{3} ; 24$ - Eostaffella designata (D. Zeller); p. Кальміус, смт. Старобешеве, вознесенський горизонт, вапн. $\mathrm{D}_{7}^{3}$; 25 - Eostaffella postproikensis Vdov.; правий берег р. Кальміус, смт. Старобешеве, запалтюбинський горизонт, вапн. $\mathrm{D}_{5}^{5} ; 26$ - Eostaffella kashirica Raus.; с. Олександрівка, Старобешівський p-н, фенінський горизонт, вапн. $\mathrm{E}_{5}$; 27 - Plectostaffella sp.; p. Кальміус, б. Безіменна, смт. Старобешеве, запалтюбинський горизонт, вапн. D7; 28-30 - Plectostaffella varvariensis (Brazhn. et Pot.); 28 - р. Кальміус, б. Желвакова, смт. Старобешеве, вознесенський горизонт, вапн. $D_{5}^{9} ; 29$ - там само, вапн. $D_{5}^{10} ; 30$ - б. Широка, с. Григорівка, Амвросіївський р-н, феннінський горизонт, вапн. $\mathrm{E}_{6}$; 31 - Plectostaffella cuboides Rum.; правий берег р. Берестова, с. Олександрівка, Старобешівський р-н, вознесенський горизонт, вапн. D5; 32 - Plectostaffella reitlingeri Groves; там само; 33, 34 - Plectostaffella jakhensis Reitl.; урочище «Чорна скеля», лівий берег р. Берестова, смт. Старобешеве, френінський горизонт, вапн. Е - Plectostaffella bogdanovkensis Reitl.; 35 - р. Кальміус, б. Безіменна, смт. Старобешеве, вознесенський горизонт, вапн. $D_{5}^{9} ; 36$ - р. Кальміус, смт. Старобешеве, вознесенський горизонт, вапн. $\mathrm{D}_{7}^{2} ; 37$ - Plectostaffella varvariensiformis Brazhn. et Vdov.; р. Кальміус, б. Желвакова, смт. Старобешеве, вознесенський горизонт, вапн. D룽 38,39 Millerella uralica Kir.; р. Кальміус, смт. Старобешеве, вознесенський горизонт, вапн. $D_{7}^{4} ; 40$ - Millerella angusta (Kir.); р. Кальміус, б. Желвакова, смт. Старобешеве, вознесенський горизонт, вапн. $\mathrm{D}_{5}^{10} ; 41$ - Millerella pressa Thomp.; р. Кальміус, б. Безіменна, смт. Старобешеве, вознесенський горизонт, вапн. $\mathrm{D}_{5}^{9} ; 42$ - Plectomillerella subacuta; р. Кальміус, б. Желвакова, смт. Старобешеве, запалтюбинський горизонт, вапн. $\mathrm{D}_{5}^{10} ; 43,44$ - Millerella marblensis Thomp.; 43 - р. Кальміус, смт. Старобешеве, вознесенський горизонт, вапн. D; ; 44 - б. Широка, с. Григорівка, Амвросіївський р-н, фенінський горизонт, вапн. $\mathrm{E}_{1} \mathrm{H} ; 45,46$ - Semistaffella minuscilaria (Reitl.); 45 - б. Широка, с. Григорівка, Амвросіївський р-н, фенінський горизонт, вапн. $E_{1}$ н; 46 - урочище «Чорна скеля», лівий берег р. Берестова, смт. Старобешеве, фенінський горизонт, вапн. $\mathrm{E}_{1}^{0} ; 47$ - Semistaffella aff. minuscilaria (Reitl.); урочище «Чорна скеля», лівий берег р. Берестова, смт. Старобешеве, фенінський горизонт, вапн. $\mathrm{E}_{3}$; 48 - Semistaffella aff. primitiva (Reitl.); там само; 49 - Semistaffella sp.; там само, вапн. $\mathrm{E}_{2}^{1} ; 50$ - Semistaffella variabilis (Reitl.); там само, вапн. $\mathrm{E}_{3} ; 51,52$ - Semistaffella aff. variabilis (Reitl.); 51 - c. Олександрівка, Старобешівський р-н, фенінський горизонт, вапн. $\mathrm{E}_{4} ; 52$ - б. Широка, с. Григорівка, Амвросіївський р-н, френінський горизонт, вапн. $\mathrm{E}_{7} ; 53-$ Eostaffella parastruvei (Raus.); - р. Кальміус, б. Желвакова, смт. Старобешеве, запалтюбинський горизонт, вапн. $D_{5}^{8} \mathrm{H} ; 54-$ Eostaffella mirifica Brazhn.; урочище «Чорна скеля», лівий берег р. Берестова, смт. Старобешеве, фенінський горизонт, вапн. $E_{1}^{0} ; 55$ - Eostaffella ikensis Viss.; правий берег р. Кальміус, смт. Старобешеве, запалтюбинський горизонт, вапн. D5; 56 - Seminovella elegantula Raus.; р. Кальміус, смт. Старобешеве, вознесенський горизонт, вапн. $\mathrm{D}_{7}^{4} ; 57$ - Seminovella aff. donetziana Pot.; там само; 58 - Seminovella fragilis Vak.; там само; 59 - Millerella extensa Marshall; б. Широка, с. Григорівка, Амвросіївський p-н, френінський горизонт, вапн. $\mathrm{E}_{6}$

souriensum Johns., синьозелені водоростi Girvanella problematica Nich. et Ether, G. wetheredii Chapm., Girvanella minuta Weth., Stipulella fascicularis Masl., зелені водорос- ті родів Calcifolium, Gyroporella, Nanopora, Fasciella, Aphralysia. Кальціфоліуми, гірванели та фасціели часто є породоутворюючими. 
Таблиця II
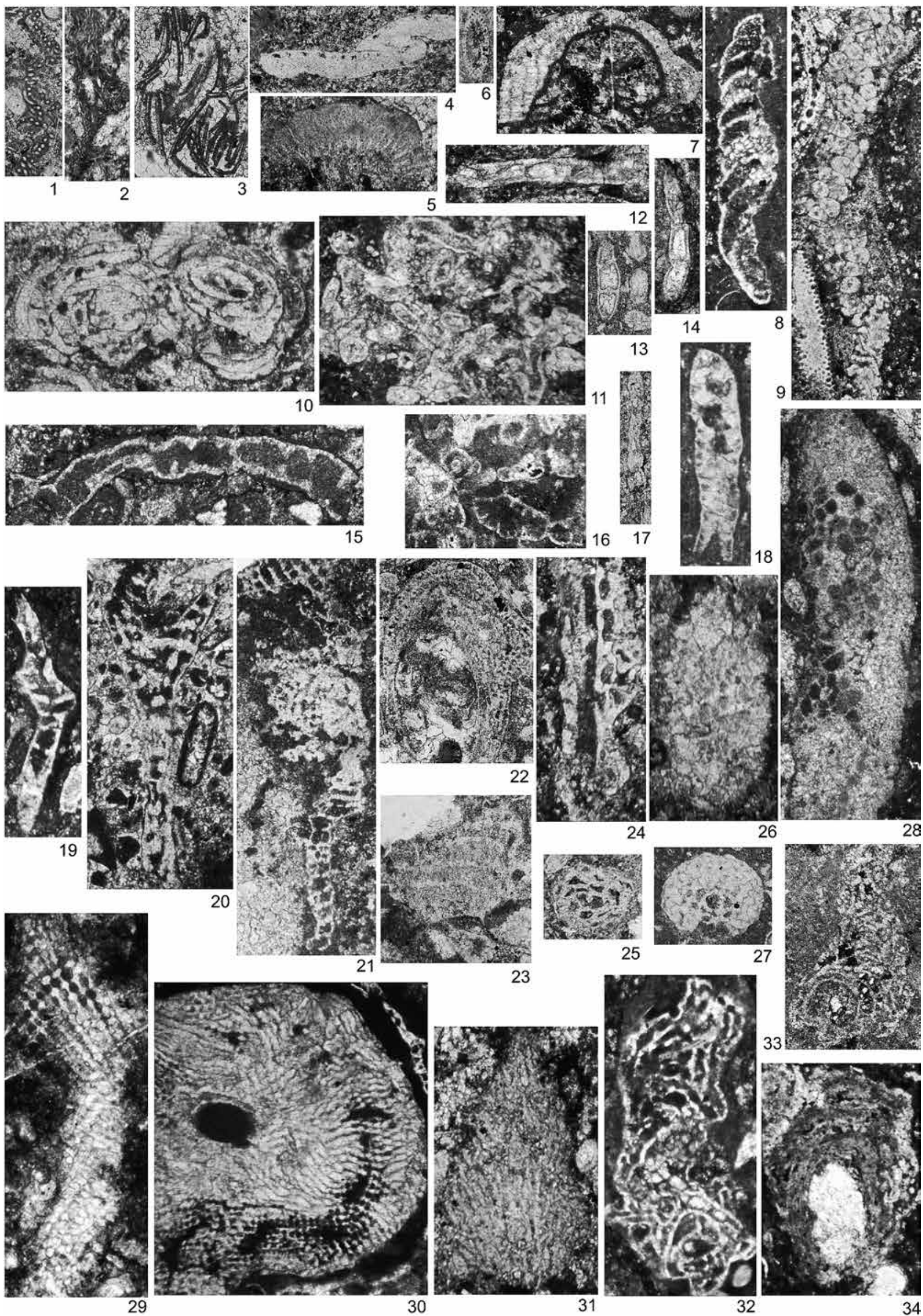

20
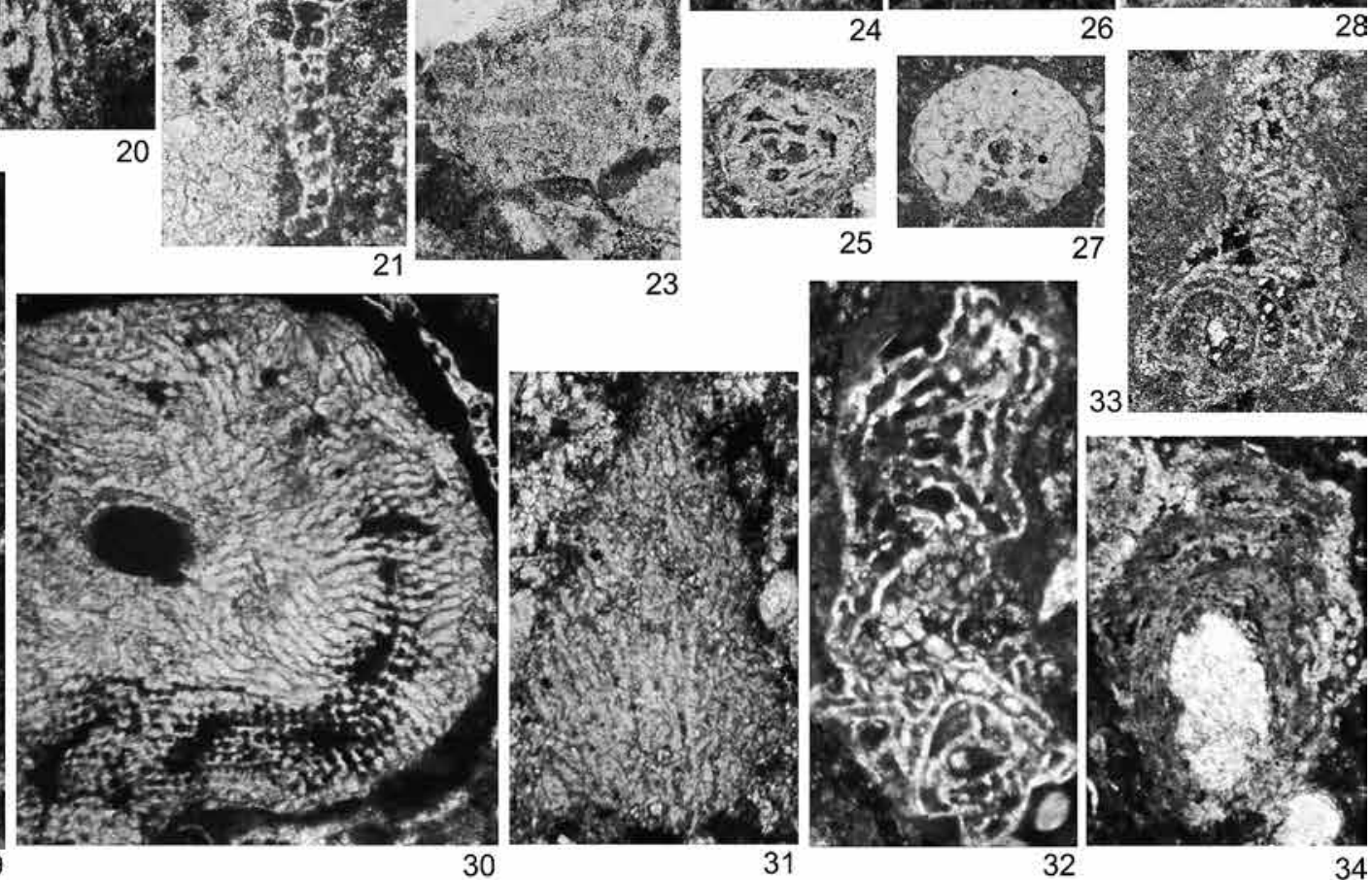
Таблиця II

Стратиграфрічно важливі види вапнистих водоростей в пограничних міссісіпсько-пенсільванських відкладах x 50

1 - Girvanella problematica Nich. et Ether.; правий берег р. Кальміус, смт. Старобешеве, запалтюбинський горизонт, вапн. $\mathrm{D}_{5} ; 2$-Girvanella minuta Weth.; г. Запал-Тюбе, с. Вознесенка, Старобешівський р-н, запалтюбинський горизонт, вапн. $\mathrm{D}_{5}^{2} ; 3$ - Stipulella fascicularis Masl.; б. Султан-Бій-Тарама, правий берег р. Кальміус, Старобешівський р-н, запалтюбинський горизонт, вапн. $\mathrm{D}_{3} ; 4,5$ - Calcifolium okense Schvetz. et Bir.; 4 - p. Кальміус, смт. Старобешеве, запалтюбинський горизонт, вапн. $\mathrm{D}_{3}$; 5 - c. Роднікове, Старобешівський р-н, запалтюбинський горизонт, вапн. $\mathrm{D}_{3}$; 6 - Nanopora anglica Wood; p. Кальміус, смт. Старобешеве, запалтюбинський горизонт, вапн. $\mathrm{D}_{3} ; 7$ - Fourstonella fusiformis (Brady); смт. Старобешеве, запалтюбинський горизонт, вапн. $\mathrm{D}_{4}$; 8 - Stacheia marginulinoides Brady; правий берег р. Берестова (біля Старобешівського водосховища), вознесенський горизонт, вапн. $\mathrm{D}_{7}^{7} ; 9$-Nostocites vesiculosa Masl.; смт. Старобешеве, вознесенський горизонт, вапн. $\mathrm{D}_{7}^{1} ; 10$ - Fasciella kizilia R. Iv.; - p. Берестова, c. Обільне, Старобешівський р-н, запалтюбинський горизонт, вапн. $\mathrm{D}_{5} ; 11,12$ - Praedonezella cespeformis Kul.; г. Запал-Тюбе, с. Вознесенка, Старобешівський р-н, запалтюбинський горизонт, 11 - вапн. $\mathrm{D}_{5}, 12-$ вапн. $\mathrm{D}_{5}^{2}$; 13 , 14 - Donezella lutugini Masl.; 13 - с. Олександрівка, Старобешівський р-н, фенінський горизонт, вапн. $\mathrm{E}_{5} ; 14$ - б. Широка, с. Григорівка, Амвросіївський р-н, фенінський горизонт, вапн. Е $;$; 15 - Claracrusta catenoides (Homann); р. Кальміус, б. Желвакова, смт. Старобешеве, вознесенський горизонт, вапн. $D_{5}^{8} \mathrm{~B} ; 16$ - Proninella strigosa (Vachard); г. Запал-Тюбе, с. Вознесенка, Старобешівський р-н, запалтюбинський горизонт, вапн. $\mathrm{D}_{3} ; 17$ - Einoriella elongata Salt.; б. Широка, с. Григорівка, фенінський горизонт, вапн. $\mathrm{E}_{1}$; 18 - Dvinella bifurcata Masl.et Kul.; p. Берестова, с. Обільне, Старобешівський р-н, запалтюбинський горизонт, вапн. $\mathrm{D}_{5}^{4}$; 19-21 - Masloviporidium delicata (Berch.); 19 - р. Кальміус, б. Желвакова, смт. Старобешеве, вознесенський горизонт, вапн. $\mathrm{D}_{5}^{8} \mathrm{~B} ; 20$ - p. Берестова, с. Обільне, Старобешівський р-н, вознесенський горизонт, вапн. $\mathrm{D}_{7} ; 21$ - б. Попова, вознесенський горизонт, вапн. $\mathrm{D}_{7}^{7} ; 22$ - Cuneiphycus aliquantulus Johns.; c. Олександрівка, Старобешівський р-н, фенінський горизонт, вапн. $\mathrm{E}_{5}$; 23 - Cuneiphycus texana Johns.; там само; 24, 25 - Aoujgalia ellioti Mam. et Roux; 24 - правий берег р. Кальміус, смт. Старобешеве, запалтюбинський горизонт, вапн. $D_{5}$; 25 - p. Берестова, с. Обільне, Старобешівський р-н, запалтюбинський горизонт, вапн. $\mathrm{D}_{5}^{4}$; 26, 27 - Aoujgalia sp.; 26 - правий берег р. Кальміус, смт. Старобешеве, запалтюбинський горизонт, вапн. $\mathrm{D}_{5}^{1} ; 27$ - правий берег $\mathrm{p}$. Берестова, запалтюбинський горизонт, вапн. $\mathrm{D}_{5}^{4} ; 28$ - Archaeolithophyllum missouriensum Johns.; p. Кальміус, б. Желвакова, смт. Старобешеве, запалтюбинський горизонт, вапн. $\mathrm{D}_{5}^{8} \mathrm{H} ; 29$ - Cuneiphycus sp.; б. Широка, с. Григорівка, Амвросіївський р-н, фенінський горизонт, вапн. $\mathrm{E}_{7} ; 30$ - Ungdarella peratrovichensis Mam. et Rudl.; лівий берег р. Кальміус, смт. Старобешеве, запалтюбинський горизонт, вапн. $\mathrm{D}_{5}$; 31 - Ungdarella uralica Masl.; смт. Старобешеве, запалтюбинський горизонт, вапн. $\mathrm{D}_{5}$; 32 - Stacheoides meandriformis Mam. et Rudloff; p. Кальміус, б. Желвакова, смт. Старобешеве, вознесенський горизонт, вапн. $\mathrm{D}_{5}^{8} \mathrm{~B} ; 33$ - Stacheoides tenuis Petr. et Mam.; там само, запалтюбинський горизонт, вапн. $\mathrm{D}_{5}^{5}$; 34 - Stacheoidella spissa (Petr. et Mam.); там само, вознесенський горизонт, вапн. $\mathrm{D}_{5}^{8} \mathrm{~B}$

Систематичний склад водоростей суттєво змінюється на початку вознесенського часу (на рівні вапняків $D_{5}^{8} B-D_{5}^{9}$ ) - поновлюється представниками нових родів Masloviporidium delicata (Berch.) i Donezella sp. одночасно зі зникненням кальціфоліумів та фасціел. Частими у вознесенських відкладах $є$ багрянки Eflugelia johnsoni (Flugel), Stacheia marginulinoides Brady, Stacheoides tenuis Petr. et Mam. та ін.

Значне оновлення складу водоростей відбувається також у світі $\mathrm{C}_{2}^{0}(\mathrm{E})$. На початку фенінського часу (з вапняку $E_{1} \mathrm{H}$ ) з'являються перші представники роду Einoriella - Einoriella elongata Salt., принципово нового роду Cuneiphycus - Cuneiphycus texana Johns., Archaeolithophyllum johnsoni Racz, Donezella lutugini Maslov та ін.

Таким чином, найбільш вагомі зміни в еволюції форамініфер та водоростей Донбасу у перехідний ранньосередньокам'яновугільний час відбувались з початку формування вознесенського горизонту (рівень вапняків $\mathrm{D}_{5}^{8} \mathrm{~B}-\mathrm{D}_{5}^{9}$ ). У Північній Америці ця границя приблизно збігається зі зникненням еосигмоілін і появою видів Globivalvulina bulloides, Millerella pressa, $M$. marblensis. Важливим фрактом $€$ фріксація даних видів у Донбасі. Одночасно зі зникненням у вапняку $D_{5}^{9}$, тобто в перехідному інтервалі амоноїдних зон EumorphocerasHomoceras та в основі конодонтової зони Declinognathodus noduliferus s. I. [12], стратиграфрічно важливого роду Eosigmoilina та виду Loeblichia minima Brazhn., зафріксовано появу перших мілерел - Millerella angusta, M. pressa. На цьому ж рівні у Донбасі з'являються водорості Masloviporidium delicata i Donezella sp., що починають складати основний фон башкирської альгофлори. За нашими даними, Globivalvulina bulloides тут з'являється дещо пізніше, а саме в середині згаданих амоноїдної та конодонтової зон [18] на рівні вапняку $D_{7}^{2}$, коли з'являються 
B.I. ЄФIMEHKO

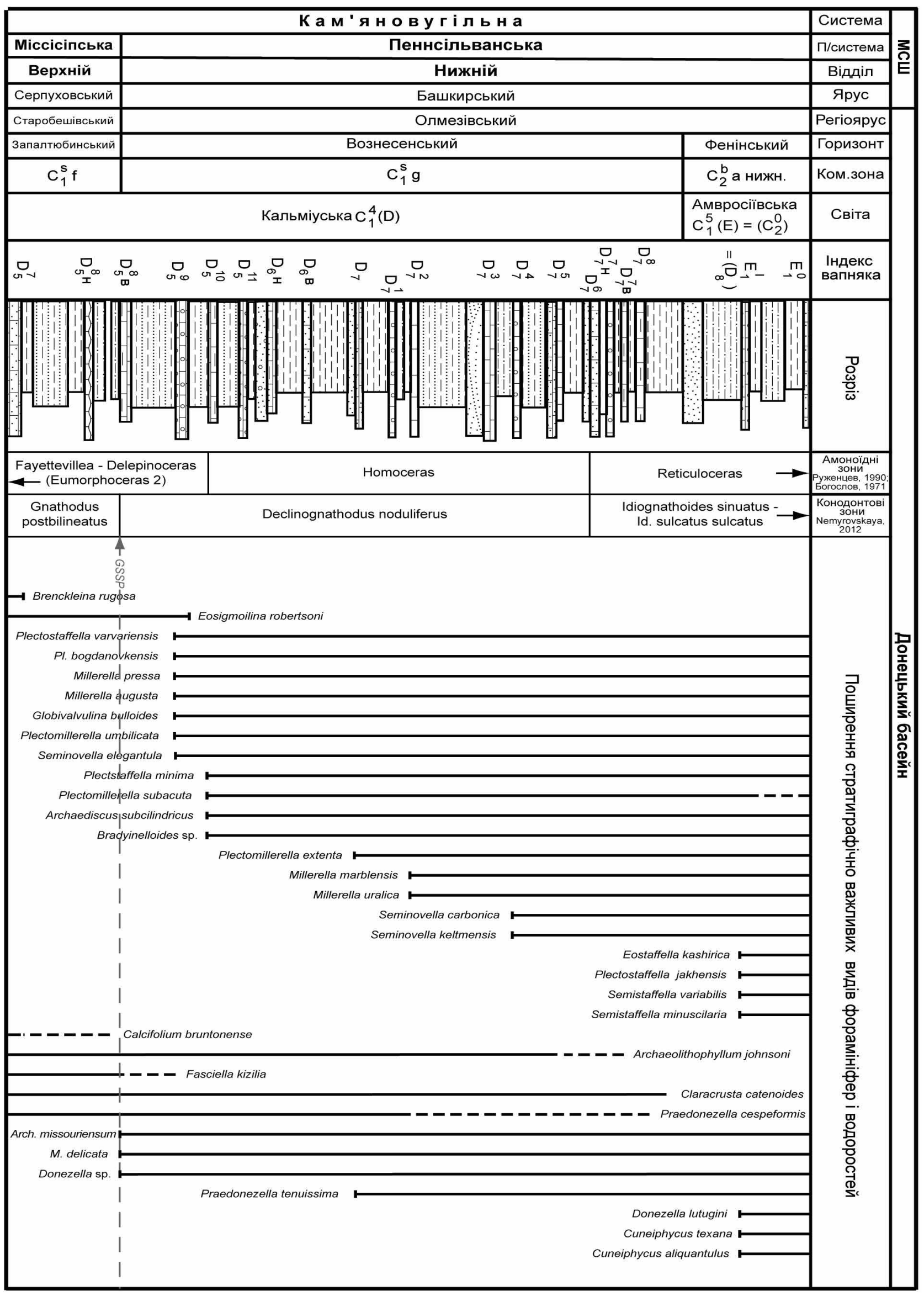

Рис.1. Поширення стратиграфрічно важливих видів форамініфер і вапнистих водоростей в пограничних нижньо-середньокам'яновугільних відкладах Донбасу 
сплощені форми Millerella marblensis та M. uralica.

Повноцінне відродження фрауни форамініфер у Донецькому басейні почалося 3 початком нової значної трансгресії башкирського часу, яка майже збіглася з початком амоноїдної зони Reticuloceras. На цьому рубежі з'являються Semistaffella - перші представники родини Pseudostaffellidae, яка у башкирський час буде домінуючою у фрауні форамініфрер. Приблизно на цьому ж рівні (починаючи 3 вапняків $\mathrm{E}_{1} \mathrm{H}$ та $\mathrm{E}_{1}^{0}$ ), як зазначалось вище, відбувається значне оновлення водоростевого комплексу.

\section{ВИСНОВКИ}

Таким чином, у перехідний ранньосередньокам'яновугільний час в еволюційному розвитку форамініфер і водоростей Донбасу виявлено три найбільш суттєвих рубежів: кінець запалтюбинського - початок вознесенського горизонту (рівень вапняків $\left.\mathrm{D}_{5}^{8} \mathrm{~B}-\mathrm{D}_{5}^{9}\right)$, середина вознесенського горизонту (рівень вапнку $D_{7}^{2}$ ), початок френінського горизонту (рівень вапняку $\mathrm{E}_{1}$ ). 3 урахуванням сучасних вимог стратиграфії виявлені регіональні та планетарні біологічні маркери для обгрунтування серединної границі карбону у Донбасі. Основним критерієм проведення серединної границі карбону у Донбасі, на нашу думку, є поява плектоштафел з чіткими і стійкими видовими ознаками: Plectostaffella bogdanovkensis та PI. varvariensis, Millerella angusta, M. pressa та водоростей Masloviporidium delicata i Donezella sp. Вид-індекс Plectostaffella berestovensis Brazhn. et Vdov. форамініфрерової зони, виділеної раніше в основі вознесенського горизонту Донбасу [21], ми вважаємо через нечіткі діагностичні ознаки не придатним для фріксації серединної границі карбону. Другорядним критерієм границі може слугувати зникнення фрорамініфрер Eosigmoilina robertsoni та водоростей родів Fasciella i Calcifolium. Появу Millerella marblensis, $M$. uralica та Globivalvulina bulloides також можна вважати додатковим критерієм встановлення границі $\mathrm{C}_{1}-\mathrm{C}_{2}$ у Донбасі.

1. Бражнікова Н.Є. Про зміну фрауни форамініфер на межі нижнього та середнього карбону Донбасу // Геол. журн. - 1951. - Т. 11, вип. 3. - С. 29-45.

2. Давыдов В.И. Каменноугольная система и современный статус ее подразделений // Стратиграфия и палеогеография карбона Евразии. - Екатерин- бург: Изд-во Ин-та геологии и геохимии УрО РАН, 2002. - C. 72-91.

3. Єфріменко B.І. Історія розв'язання проблеми серединної границі карбону в Донбасі // Теоретичні та прикладні аспекти сучасної біостратиграфії фанерозою України: Зб. наук. пр. ІГН НАН України. - К., 2003. - C. 81-83.

4. Иванова Р.М., Кулагина Е.И., Румянцева З.С. и др. К проблеме границы нижнего и среднего карбона в Донбассе, Тянь-Шане и на Урале // Бюл. Моск. о-ва испытытелей природы. Отд. геол. - 1992. - Т. 67, вып. 2. - С. 80-91.

5. Рейтлингер Е.А. Этапность как критерий проведения биостратиграфических границ на примере каменноугольной системы (по фораминиферам) // Стратиграфия карбона и геология угленосных формаций СССР. - М.: Недра, 1975. - С. 17-25.

6. Рейтлингер Е.А. Этапность развития фораминифер и ее значение для стратиграфии каменноугольных отложений // Вопр. микропалеонтологии. - 1969. - Вып. 12. - С. 3-33.

7. Решения Межведомственного регионального стратиграфического совещания по среднему и верхнему палеозою Русской платформы: карбоновая система. - Л.: ВСЕГЕИ, 1990.

8. Стратиграфрическая схема нижнекаменноугольных отложений восточных областей Украины // Стратиграфические схемы фанерозоя и докембрия Украины. - Киев, 1993.

9. Стратиграфрическая схема среднекаменноугольных отложений восточных областей Украины // Стратиграфические схемы фанерозоя и докембрия Украины. - Киев, 1993.

10. Brenckle P.L., Baesemann J.F., Lane et al. Arrow Canyon, the Mid-Carboniferous Boundary Stratotype /I XIII ${ }^{\text {th }}$ International Congress, Carboniferous Stratigraphy and Geology, Krakow (1995) Proceedings. - Krakow, 1997. - Part 3. - P. 149-164.

11. International Stratigraphic Guide. A Guide to stratigraphic classification, terminology and procedure. - 1976. $-200 \mathrm{p}$.

12. Grossman E.L., Mii Horng-Sheng, Yancey T.E. Stable isotopes in Late Pennsylvanian brachiopods from the United States; implications for Carboniferous paleoceanography // Geol. Soc. Amer. Bull. - 1993. Vol. 105, No. 10. - P. 1284-1296.

13.Lane H.R., Brenckle P.L., Baesemann J.F., Richards $B$. The IUGS boundary in the middle of the Carboniferous: Arrow Canyon, Nevada, USA // Episodes. - 1999. - Vol. 22, No. 4. - P. 272-283.

14. Menning M., Alekseev A.S., Chuvashov B.I. et al. Global time scala and regional stratigraphic reference scales of Central and West Europe, East Europe, Tethys, South China, and North America as used in the Devonian-Carboniferous-Permian Correlation Chart 2003 (DCP 2003) // Palaeogeography, Palaeoclimatology, Palaeoecology. - 2006. - Vol. 240. - P. 318-372. 
15. Mii Horng-Sheng, Grossman E.L., Yancey T.E. et al. Isotopic records of brachiopod shells from the Russian Platform evidence for the onset of midCarboniferous glaciation // Chemical Geology. 2001. - Vol. 175, No. 1-2. - P. 133-147.

16. Nemyrovska T.I. Bashkirian conodonts of the Donets Basin // Scripta Geologica. - 1999. - 115 p.

17. Nemirovskaya T.I., Poletaev V.I., Vdovenko M.V. The Kal'mius section, Donbass, Ukraine, U.S.S.R.: A Soviet proposal for the Mid-Carboniferous boundary stratotype // Palaeogeography, Palaeoclimatology, Palaeoecology. - 2006. - Vol. 240. - P. 247-272.

18. Nemyrovska T., Winkler Prins C.F., Wagner R. The Mid-Carboniferous boundary in the Cantabrian Mountains (N. Spain) // Проблеми стратиграфіï кам'яновугільної системи: Зб. наук пр. - К., 2008. С. 69-86.
19. Poletaev V.I., Brazhnikova N.E., Vasilyuk N.P., Vdovenko M.V. Local zones and Major Lower carboniferous biostratigraphic boundaries of the Donets basin (Donbass), Ukraine, U.S.S.R. // Courier Forsch. - Inst. Senckenberg, 130. - Frankfurt a. M., 1990. - P. 47-59.

20. Popp B.N., Anderson Th.F., Sandberg P.A. Brachiopods as indicators of original isotopic compositions in some Paleozoic limestones // Geolog. Soc. Amer. Bull. 1986. - Vol. 97, No. 10. - P. 1262-1269.

21. Vachard D., Maslo A. Precisions biostratigraphiques et micropaleontologiques sur le Bashkirien d'Ukraine (Carbonifere moyen) // Revue de Paleobiologie. Geneve, 1996. - Vol. 15, No 2. - P. 357-383.

Інститут геологічних наук НАН України, Київ E-mail: evi2_2@yahoo.com 